\title{
PROCESS MANAGEMENT OF OCCUPATIONAL SAFETY IN AN ENTERPRISE EXEMPLIFIED BY CON- STRUCTION INDUSTRY
}

\begin{abstract}
The paper presents the role and importance of occupational safety and health management of employees for the company functioning. The idea of the process organization and process management of health and safety in the company was presented. It shows the current state of safety in the construction industry together with an indication of the most common abnormalities in the industry.
\end{abstract}

\section{INTRODUCTION}

Today, the issue of safety at work has gone far beyond the purely economic dimension of the activities of enterprises. The companies are obliged to include in the scope of its objectives, mission and strategy the issues related to occupational safety and ergonomics, as a major platform for regulating business relations with the surrounding social and organizational environment.

Ineffectiveness of the existing methods of improving the organization and strong competition are forcing companies to look for new solutions in this area, resulting in the emergence of the concept of process management. This concept is based on the assumption that at the current stage of development, improving the functioning of the organization by improving its individual action is ineffective, since only the entire sequence of actions, i.e. processes contribute to the organization's strategy ${ }^{2}$. Process approach to managing the organization focuses primarily on operational processes which are key from the point of view of doing business.

Processes for managing health and safety are essential because on the one hand they help to ensure the smooth functioning of the company, on the other one allow to meet the legal requirements for safety and health at work. Furthermore, the use of a process approach in the management of occupational health and safety can help businesses to implement and maintain a safety management system and occupational health.

\section{OCCUPATIONAL SAFETY AND MANAGEMENT OF EMPLOYEES' HEALTH}

Due to significant changes in the world of work in the last 20 years in Europe, including Poland, there are grounds for a new approach to occupational health policy and infrastructure changes to support the company in the management of health and safety of

\footnotetext{
${ }^{1}$ Renata Piętowska-Laska, PhD, Eng, Department of Management Systems and Logistics, Faculty of Management, Rzeszow University of Technology.

${ }^{2}$ T. Izydorczyk, M. Pęciłło, System zarzadzania bezpieczeństwem i higiena pracy w ujęciu procesowym, Wydawnictwo CIOP-PIB, Warszawa 2005, s. 5.
} 
workers ${ }^{3}$. To achieve the, it is necessary a holistic and proactive approach in a company to the management of determinants of health and human resources, while using methods and knowledge of traditional professional control of health and safety hazards.

There are companies in Europe, especially on the international level, which effectively take extensive measures to improve or maintain the health and work ability of employees, in the belief that they can in this way to strengthen their market position and achieve competitive advantage. The scope of these activities can be very broad and include the following pro-health investments ${ }^{4}$ :

- protection of health and safety of workers against occupational hazards in the workplace - the responsibility of employers in this area is usually defined by law,

- $\quad$ promotion of health, including mental health, healthy lifestyles and the prevention of chronic non-communicable diseases of civilization (such as cardiovascular and muscular-skeletal illnesses, mental disorders) through the right work culture, work organization and providing employees with social support and participation in the company policy of health protection,

- $\quad$ investing in improving the knowledge and professional skills of employees,

- $\quad$ efficient use of natural resources and protection of the environment against pollution.

The concern about compliance with the laws governing the realm of safety, as well as a large emphasis on the technical level of the used machinery, equipment and tools and the correct procedures governing the supervision of the work conditions and allowing for monitoring of working conditions is obvious and always required. However, as shown by recent studies in companies only $30 \%$ of accidents are caused by breakdowns and malfunctions of machines. Other causes lie in the attitudes and behaviors of managers and workers of enterprises. Therefore, one of the basic principles of management as defined by the security policy should be the creation of a proactive health management system at work. It is mainly conditioned by the common ergonomic risk in the organization, manifested primarily by the deterioration of the health risks that are a source of risk resulting from non-compliance with the requirements of ergonomics in the workplace. The sources of ergonomic hazards result on the one side from the employee's mental and physical capabilities, on the other hand does not meet the requirements of ergonomic work station, work process or the organization ${ }^{5}$. Therefore, for better care for the safety and health of the workers one should seek to optimize the form of the company. Currently, the best solution in this field is the form of process organization.

\section{AN IDEA OF PROCESS ORGANISATION}

The process organization provides a larger dynamics of the organization system operation than the classical form, while allowing for better use of the resources available in today's organizations. The process approach is based on the assumption that the operation

\footnotetext{
${ }^{3}$ Prognoza ekspertów dotyczqca nowych, pojawiajacych się ryzyk zwiqzanych z czynnikami fizycznymi w środowisku pracy (Export forecast on emerging physical risks related to occupational safety and health), Europejska Agencja Bezpieczeństwa i Zdrowia w Pracy, http://osha.eu.it [dostęp 20 marca 2007].

${ }^{4}$ Krajowa polityka w zakresie zdrowia pracujacych, http://rop.sejm.gov.pl_1_Old_opracowania_pdf_material26 [dostęp 12 października 2012].

${ }^{5}$ Por. W. Horst, N. Horst, Zarzqdzanie ryzykiem ergonomicznym na stanowisku pracy, „Promotor” 2006, nr 7-8, s. 45.
} 
should be optimized, with regard to the processes rather than the functions, and therefore the process is a natural determinant of achieving the growth in efficiency of modern organization.

The basic principle which is used to build the configuration of operations team is their division into parts, so that they become comprehensible and rapidly controlled by a man. Such the category is the process which is treated as a dynamic object upon which the system of inter-organization relationships are built.

There is a huge variety and diversity of approaches to define processes. M. Hammer and J. Champy understand the processes as a set of actions giving an effort at the input, thus at the output of the process they trigger an effect - the effect of carrying value to the customer $^{6}$.This is a radical approach to reorganization.

Particularly noteworthy is the second definition of the process provided by the American scientist T.H. Davenport who presented a pragmatic approach to the reorganization of the business, based on the gradual evolution and the participation of workers. According to him, the process is a structured, measured set of activities designed to create a specific product and/or service to the customer and/or market, the consequence is a strong emphasis, "how it is done in the organization," and not as so far "what is done in the organization." The process understood in that way goes beyond the limits of time and space, and has precisely defined beginning and end and clearly defined inputs and outputs ${ }^{7}$.

Sz. Cyfert provides the definition of the process, according to which the process is a chain of logically related activities involving the transformation of resource inputs such that the value of the result at the output - from the point of view of the customer - is higher than the value of the investment at the entrance ${ }^{8}$.

For the purposes of this analysis, the process definition by P. Grajewski was adopted, where the process is a set of sequential steps related with the cause and effect relationships in the sense that the results are input actions preceding the ensuing action. Any action or set of actions can be described as a process by which from the initial value, i.e. the effort we get the result - so the effort transformed and enriched with added value - which is the result of the process 9 .

J. Brilman believes that a process-oriented organization occurs when ${ }^{10}$ :

- there were identified the processes the number of which should not exceed a few dozen,

- $\quad$ there were constructed the maps of processes relationship

- $\quad$ there is a system of measuring the results of processes,

\footnotetext{
${ }^{6}$ M. Hammer, J. Champy, Reengineering w przedsiębiorstwie, Neumann Management Institute, Warszawa 1996, s. 25.

${ }^{7}$ T.H. Davenport, Process Innovation - Reengineering Work through Information Technology, Harvard Business School Press, Boston 1993, s. 5. T.H. Davenport uważał, że orientacja na procesy biznesu w przedsiębiorstwie jest podstawą zastosowań technik informacyjnych (IT). Szerzej: Modele referencyjne w zarzadzaniu procesami biznesu, red. T. Kasprzak, Difin, Warszawa 2005, s. 25-26.

${ }^{8}$ Sz. Cyfert, Strategiczne doskonalenie architektury procesów w zarzq̨dzaniu przedsiębiorstwem, Wydawnictwo Akademii Ekonomicznej w Poznaniu, Poznań 2006, s. 22.

${ }^{9}$ P. Grajewski, Organizacja procesowa. Projektowanie i konfiguracja, PWE, Warszawa 2007, s. 55.

${ }^{10}$ Sz. Cyfert, Strategiczne doskonalenie architektury procesów w zarzqdzaniu przedsiębiorstwem, op. cit., s. 27; J. Brilman, Nowoczesne koncepcje i metody zarzadzania, PWE, Warszawa 2002, s. 302.
} 
- $\quad$ there is implemented a process of processes management aimed at the permanent improvement.

The characteristic features of the process organization include ${ }^{11}$ :

- $\quad$ aiming to simplify the processes of the enterprise,

- $\quad$ implementation within the organization the principles of the client-supplier relationships which in practice gives members of the process organization the rights to negotiate among themselves the conditions of implementation and acceptance of business partners work

- the nature of the team work in the process organization which means the extension of its subjectivity,

- decentralization of power in the company which means that employees not only receive sequential tasks to be performed, but they are delegated the authority and powers previously reserved for managers,

- the salary base are the effects, not the implementation; focusing on outcomes will determine the actual results generated on the basis of the value that can be easily measured,

- designing the run of operations in the processes of adjustment to the contract in order to get as much as possible the effect of the adjustment to the process organization to the complex level of meeting customer's expectations,

- configuration of the organizational structure including the pro-customer direction of inter-organization relationships.

Process management is an activity consisting in optimizing the structure of the elements of the organization. It is therefore important to try to maximize participation in the structure of the elements that add value and minimize the share of inefficient operations. In practice it means searching for such structure of the operation, i.e. the components of the process, which would be directed to create added value for the whole organizational system, and thus its individual parts ${ }^{12}$.

However, there are some restrictions on the implementation of the ideal process structure in the organizational reality of companies. Inability to move it to the ground of today's organizations results from existing technological conditions, as well as the level of organizational culture and existing business skills at the disposal of workers. This means that the concepts of the ideal process organization should be treated as the demand and the target proposal of solutions in the area of organization and management. However, this desideratum can be partially achieved by imposing process structure on the existing functional structure. This will allow to build the system of process management.

The main objective of process management is to improve the efficiency of the company by structuring operations for creating added value with a special focus on the prefe-

\footnotetext{
${ }^{11}$ Por. Sz. Cyfert, Strategiczne doskonalenie architektury procesów w zarzq̨dzaniu przedsiębiorstwem, op. cit., s. 27; W.M. Grudzewski, I.K. Hejduk, Metody projektowania systemów zarzqdzania, Difin, Warszawa 2004, s. 61-63.

${ }^{12}$ P. Grajewski, Organizacja procesowa. Projektowanie i konfiguracja, op. cit., s. 56.
} 
rences and needs of the customer and the relevant description and setting up business processes according to the criteria of time and space ${ }^{13}$.

The rapid pace of economic and technological changes and the increase in the degree of complexity gives a rise to new organizational structures that cannot only adapt to change but also overtake them. The company must still undertake the task of adapting behavior to the existing reality. The organization must therefore be viewed as an integrated system of processes, rather than a collection of functional tasks of separate units. Thus, it becomes necessary to search for quantitative and qualitative factors determining the effectiveness of the organization and commitment to the process of the entire staff.

The company management process is carried out by taking decisions. In classic terms one can distinguish three levels of decision-making management : strategic, tactical and operational. Some authors even add a fourth level, called the level of network management. However, in a dynamic notion, it is justified to modify existing levels and award the following: a strategic, process and function one. Strategic level, covering an area of company development decisions, is a crucial field of key decision-makers and the company's board. Process level is a set of functions assigned to the relevant departments for which the middle-level management is responsible. However, in the function level, for which the other employees are responsible for, the function is defined as a set of specific tasks assigned to employees to perform ${ }^{14}$.

The organization which treats process management as a priority should follow some proven principles that ensure the effective implementation of a new quality management company. Wherever the orientation for processes was successful ${ }^{15}$ :

- the introduction of process management was initiated by the management of the company and actively supported, not only in the drafting of organizational solutions, but also in the implementation phase, particularly during its current operation,

- $\quad$ processes management was not limited only to certain functional areas, but covered the whole company, and has been linked to the objectives and strategy of the company,

- to work on processes there were also enrolled all the interested in the company, as well as external customers and suppliers, based on the assumption that thinking and customer-oriented action is more important than focusing on employees,

- $\quad$ process teams had clearly defined realistic goals, allocated the appropriate resources and they were cleared from the effects of their own work,

- $\quad$ process owners and process participants teams knew the basic methods and tools of management (process improvement), as previously underwent an appropriate training and workouts,

\footnotetext{
${ }^{13}$ S. Kopera, Metoda Business Process Management (BPM) jako przyklad zastosowania podejścia procesowego do zarzqdzania organizacja, [w:] Instrumenty zarzq̨dzania we wspótczesnym przedsiębiorstwie (zbiór referatów), Wydawnictwo Akademii Ekonomicznej w Poznaniu, Poznań 2000, s. 137.

${ }^{14}$ Por. Ibidem, s. 38-39.

${ }^{15}$ Procesy i projekty logistyczne, red. S. Nowosielski, Wydawnictwo Uniwersytetu Ekonomicznego we Wrocławiu, Wrocław 2008, s. 93-94.
} 
- particularly important for the successful development of the organization of the process was an open, direct and comprehensive communication about the needs, goals and ways to make changes in the company.

Actions taken by the companies, relating to the dynamic adaptation to the current and anticipated environmental conditions necessitate the need for strategies reformulation. Thus, the management of a company has to state clearly, within the strategic objectives, which processes are of particular importance and priority shall be designed, evaluated, improved and implemented.

In the company there are a number of types of processes which use a variety of criteria for this division, but the most common division is done because of the importance of the tasks performed in the organization. According to this division there can be distinguished:

- $\quad$ basic processes - resulting in the product (service) on the external market, directly related to the core business and bringing tangible benefits to the organization, most often they also include processes directly affecting the enterprise market situation, such as: product design, sales, manufacturing, customer service, logistics,

- $\quad$ support processes - resulting in the smooth functioning and support for the implementation of core processes (without auxiliary processes it is not possible the smooth functioning of the organization), in most cases they can include processes indirectly, i.e. through the basic process efficiency, market conditions affecting the company, such as: management of human resources, internal logistics, IT, financial management, market research, strategic planning.

Auxiliary processes can also include processes for managing health and safety ${ }^{16}$.

\section{PROCESS MANAGEMENT OF OCCUPATIONAL SAFETY}

There is no doubt that safe working conditions are the social and economic value so it is worth investing in it. On the return of most of these investments, however, we have to wait a certain period of time, but today one can take care of that the costs incurred in the area of health and safety were lower, and without cutting back on the purchase of protection or new machinery and equipment. Therefore, it is worth considering how this should be done. Firstly, by the right management of the resources: financial, human and material ones. Secondly, by ensuring the proper organization of work at different jobs and at the level of the entire organization, which is actually designing and implementing processes for managing health and safety. Thirdly, by conducting economic analysis in this area which will determine whether improvement actions contributed to the reduction of costs. Process approach to managing the organization focuses primarily on operational processes, i.e. the processes of added value services, so critical in terms of the business and the customer. These include, among others, processes carried out in the area of production, distribution, marketing and sales. In addition to operational processes in any organization one can also extract management processes and supportive ones i.e. those which do not create the added value in the organization but they are essential to its operation. Such processes include, among others, the process of financial management and human resource management process. Processes for managing health and safety do not create added value, but are necessary because on the one hand they help to ensure the

\footnotetext{
${ }^{16} \mathrm{M}$. Pęciłło, Identyfikacja i modelowanie procesów zarzqdzania bezpieczeństwem i higienq pracy w przedsiębiorstwie, „Bezpieczeństwo Pracy” 2003, nr 2, s. 20-21.
} 
smooth functioning of the company, on the other one, allow to meet the legal requirements for safety and health at work. Furthermore, the use of a process approach in the management of occupational health and safety can help businesses to implement and maintain a safety management system and occupational health ${ }^{17}$.

In any process of managing health and safety, one can distinguish the following elements ${ }^{18}$ :

- $\quad$ input - they can be, depending on the nature of the process for both products and services, as well as documents and information,

- $\quad$ output - as in case of the input data can be either products or services, as well as documents and information,

- $\quad$ activities carried out in the process, usually the term "action" is understood either as a single act, or a set of actions performed by one person,

- leader (owner) of the process, the person responsible for its implementation,

- the client (customer) process, that is, a person who receives information or materials and services from other people from inside or outside of the organization, resulting from the process,

- $\quad$ the supplier or a person who provides materials and information or services to other people from inside or outside of the organization,

- $\quad$ the beginning and end of the process.

Regardless of the peculiarity of the company, its size, type of business and associated risks in every company there can be identified the following processes for managing health and safety arising directly from the law ${ }^{19}$ :

- $\quad$ risk assessment process,

- the monitoring process of working conditions,

- the process of corrective and / or preventive actions,

- the process of training in occupational health and safety,

- the process of internal communication in the field of occupational health and safety,

- the process of identifying and implementing the business practices of the legal requirements of health and safety at work.

Improving organizational processes carried out in the area of health and safety at work can result in significant cost savings for companies. These savings can be estimated, especially for those processes to manage occupational health and safety which, due to the requirements of the law should be implemented in every company, regardless of whether it implements the management system of occupational health and safety in accordance with the Polish standard PN-N-18001 or not, namely for ${ }^{20}$ :

\footnotetext{
${ }^{17}$ T. Izydorczyk, M. Pęciłło, System zarzqdzania bezpieczeństwem i higiena pracy w ujęciu procesowym, op. cit., s. 6.

${ }^{18}$ Ibidem, s. 12.

${ }^{19} \mathrm{M}$. Pęciłło, Identyfikacja i modelowanie procesów zarzadzania bezpieczeństwem i higiena pracy $w$ przedsiębiorstwie, op. cit., s. 20-21; T. Izydorczyk, M. Pęciło, System zarzqdzania bezpieczeństwem i higienq pracy w ujęciu procesowym, op. cit., s. 18.

${ }^{20}$ T. Izydorczyk, M. Pęciłło, System zarzqdzania bezpieczeństwem i higiena pracy w ujęciu procesowym, op. cit., s. 6-7.
} 
- the process of hazard identification and risk assessment including corrective and / or preventive measures,

- the process of training in occupational health and safety,

- the monitoring of working conditions including corrective and/or preventive measures.

An economic analysis of the costs of management processes of safety and occupational health can estimate the economic benefits of these improvements to their processes or integration with other processes carried out in the company, for example, related to the provision of quality ${ }^{21}$ and environmental protection. Therefore, it enables to assess the desirability of improvement actions. However, one needs to remember that economic benefits are just one type of benefit. No less important is here to improve document workflows and communication, reducing the number of documents and number of activities, and clear assignment of roles and responsibilities of organizational units, which in turn leads to communication improvement between them, eliminating conflicts of competence and therefore a better functioning of the organization as a whole.

It is worth noting that the improvement of the processes is just one of the tools that could bring economic benefits to organizations in the field of occupational health and safety. No less important, from an economic point of view, is the proper functioning of the whole area of health and safety management at work that by reducing the number of accidents and occupational diseases also leads to a reduction in costs associated with occupational health and safety.

\section{OCCUPATIONAL SAFETY IN CONSTRUCTION INDUSTRY}

Construction is one of the most dangerous areas of the national economy which is characterized by a relatively high degree of danger to life and health, as well as a significant level of accidents.

Massive checks carried out by the National Labour Inspectorate (NLI) at the sites do not lead to the improvement of health and safety in construction.

A high degree of risk of accidents in the industry tends to take the issue of safety and to determine the most common irregularities on site. Based on the results of the inspection sites in Poland, carried out by the NLI inspectors it can be said that the most common irregularities on construction sites are ${ }^{22}$ :

- improper operation and maintenance of electrical installations and equipment,

- improperly constructed scaffolding,

- lack of or non-compliance by workers of personal protective equipment,

- performing work at height without security,

- improper storage of building materials and waste, and the lack of designated positions for their storage,

- use of damaged mechanical equipment, operation of cranes not allowed to work, as well as inefficient use of welding equipment,

\footnotetext{
${ }^{21}$ S. Zapłata, Zarzqdzanie jakościq w przedsiębiorstwie. Ocena i uwarunkowania skuteczności, Wydawnictwo Wolters Kluwer Polska Sp. z o.o., Warszawa 2009, s. 116

${ }^{22}$ The results of control of working conditions are based on: Report of the Chief Labour Inspector of the National Labour Inspectorate activity.
} 
- the operation of mechanical equipment with unprotected rotating elements,

- lack of proper hygiene and sanitation facilities,

- lack of proper site security against access of unauthorized persons,

- carrying out construction work without a draft organization of work, or in accordance with the project,

- carrying out earthworks in a dangerous manner, and work in the trenches without the required security,

- $\quad$ hiring workers not trained in the field of occupational health and safety,

- $\quad$ hiring workers without undergoing a required medical examination.

The best indicator of safe and healthy working conditions in the construction industry is the number of accidents at work. According to data from the National Labour Inspectorate in the period 2000-2005 there was a decline in the number of people injured in accidents at work in the construction industry. However, in the years 2006-2008, it was an increase and then a decrease in 2009 (Table 1 and 2) ${ }^{23}$.

Table 1. Accidents at work in the construction industry examined by labor inspectors in 2005-2010.

\begin{tabular}{|c|c|c|c|}
\hline Year & Total & $\begin{array}{c}\text { Including: } \\
\text { fatal }\end{array}$ & $\begin{array}{c}\text { Including: } \\
\text { grievous bodily } \\
\text { harm }\end{array}$ \\
\hline 2005 & 516 & 121 & 179 \\
\hline 2006 & 551 & 126 & 214 \\
\hline 2007 & 629 & 126 & 228 \\
\hline 2008 & 668 & 158 & 243 \\
\hline 2009 & 655 & 145 & 234 \\
\hline 2010 & 305 & 59 & 96 \\
\hline
\end{tabular}

Source: Oprac. na podst.: L. Pysznik, A. Chańska, K. Stelmach, Wypadki w budownictwie, Cz. 1, „Atest-Ochrona Pracy” 2011, nr 1, s. 4.

Table 2. Injured in accidents at work in the construction industry in the years 2005-2009.

\begin{tabular}{|c|c|c|c|}
\hline Year & $\begin{array}{c}\text { Injured in accidents } \\
\text { at work in the con- } \\
\text { struction industry }\end{array}$ & $\begin{array}{c}\text { Including: } \\
\text { fatal }\end{array}$ & $\begin{array}{c}\text { Including: } \\
\text { grievous bodily } \\
\text { harm }\end{array}$ \\
\hline 2005 & 621 & 138 & 211 \\
\hline 2006 & 632 & 153 & 231 \\
\hline 2007 & 751 & 140 & 276 \\
\hline 2008 & 764 & 170 & 275 \\
\hline 2009 & 750 & 165 & 258 \\
\hline
\end{tabular}

Source: Oprac. na podst.: L. Pysznik, A. Chańska, K. Stelmach, Wypadki w budownictwie, Cz. 1, „Atest-Ochrona Pracy” 2011, nr 1, s. 5.

Among the victims the largest group were people in age group: 40-49 years $(25.60 \%)$ and $19-29$ years $(25.50 \%)$. In the analyzed period, in controlled by NLI accidents at work

\footnotetext{
${ }^{23}$ L. Pysznik, A. Chańska, K. Stelmach, Wypadki w budownictwie, Cz. 1, „Atest-Ochrona Pracy” 2011, nr 1, s. 4.
} 
in the construction industry have been affected 2,177 people with work experience of less than one year, thus providing up $56.20 \%$ of the total victims.

The analysis of the cases examined by NLI inspectors in 2005-2010 shows that the overall structure of the causes of falls from height on the construction site are:

- technical reasons (mainly due to the wrong condition of machinery and equipment and materials) - $12.64 \%$,

- $\quad$ organizational reasons (mainly due to improper organization of work - the general organization of the establishment and organization of the work) - 47.34\%;

- $\quad$ human causes (mainly resulting from improper employee's behavior, not using protective equipment and inadequate mental and physical state, for example due to illness, fatigue, alcohol consumption) $-40.02 \%^{24}$.

Therefore, each workplace to function well and to be competitive on the market, should have an accurate understanding of the actual state of health and safety at work, appearing the risks of the health of workers and the needs in this area. This issue is important for the reason that every accident at work is not the result of a single event, but most often it is associated with the occurrence of a number of causes and factors of its creation.

For several years there has been a steady increase in interest in issues related to employers' ability to implement in their business management system, the occupational health and safety. The aim of the activities carried out in the management of health and safety at work is:

- $\quad$ to produce safe products,

- to ensure the safety of employees,

- $\quad$ to prevent threats to the safety and health of the people living in the surrounding of the plant,

- $\quad$ the prevention of risks to the environment.

Creating of this system has its deep justification in large factories which have financial resources for its development, implementation and monitoring.

\section{CONCLUSIONS}

As it results from the carried out discussions the improvement of safety and health conditions at work must be treated today not as a burdensome cost of finance companies, but as an investment that contributes to the competitiveness of the market. Such an approach seems to bring benefits to the company by increasing its finances, and at the same time influences on the employees' safety.

By implementing and modeling processes for managing health and safety in the company, it is important to remember that it is not just the aim in itself but merely a tool to contribute to the effective management of the organization. Graphical process models can be used in particular for ${ }^{25}$ :

- $\quad$ a better understanding of the functioning of the organization and to improve its efficiency in the area of safety and health at work by streamlining processes,

\footnotetext{
${ }^{24}$ L. Pysznik, A. Chańska, K. Stelmach, Wypadki w budownictwie, Cz. 2, „Atest-Ochrona Pracy” 2011, nr 2, s. 23.

${ }^{25}$ M. Pęciłło, Identyfikacja i modelowanie procesów zarzadzania bezpieczeństwem i higienq pracy w przedsiębiorstwie, op. cit., s. 23.
} 
- $\quad$ to document the procedures for the management of health and safety,

- $\quad$ an analysis of the costs of management processes of health and safety with the use of activity based costing,

- $\quad$ evaluation of the implementation of the safety and health.

Modeling of health and safety management at work can therefore be a starting point for designing a proper implementation of health and safety management in the enterprise, and can contribute to the effective functioning of the organization, expressed primarily by reducing the number of accidents at work and occupational diseases. It should be borne in mind that the data on the state of occupational health and safety in construction hides a lot of human tragedy. Therefore, no effort should be spared to improve the management of health and safety in any enterprise.

\section{REFERENCES}

[1] Brilman J., Nowoczesne koncepcje i metody zarzqdzania, PWE, Warszawa 2002.

[2] Cyfert Sz., Strategiczne doskonalenie architektury procesów w zarzadzaniu przedsiębiorstwem, Wyd. Akademii Ekonomicznej w Poznaniu, Poznań 2006.

[3] Davenport T.H., Process Innovation - Reengineering Work Through Information Technology, Harvard Business School Press, Boston 1993.

[4] Grajewski P., Organizacja procesowa. Projektowanie i konfiguracja, PWE, Warszawa 2007.

[5] Grudzewski W.M., Hejduk I.K., Metody projektowania systemów zarzqdzania, Difin, Warszawa 2004.

[6] Hammer M., Champy J., Reengineering w przedsiębiorstwie, Neumann Management Institute, Warszawa 1996.

[7] Horst W., Horst N., Zarzqdzanie ryzykiem ergonomicznym na stanowisku pracy, „Promotor” 2006, nr 7-8.

[8] Izydorczyk T., Pęciłło M., System zarzqdzania bezpieczeństwem i higienq pracy w ujęciu procesowym, Wydawnictwo CIOP-PIB, Warszawa 2005.

[9] Kopera S., Metoda Business Process Management (BPM) jako przyktad zastosowania podejścia procesowego do zarzqdzania organizacja, [w:] Instrumenty zarzqdzania we wspótczesnym przedsiębiorstwie (zbiór referatów), Wydawnictwo Akademii Ekonomicznej w Poznaniu, Poznań 2000.

[10] Krajowa polityka $w$ zakresie zdrowia pracujacych, http://rop.sejm.gov.pl_1_Old_opracowania_pdf_material26 [dostęp 12 października 2012].

[11] Modele referencyjne w zarządzaniu procesami biznesu, red. Kasprzak T., Difin, Warszawa 2005.

[12] Pęciłło M., Identyfikacja i modelowanie procesów zarzadzania bezpieczeństwem i higiena pracy w przedsiębiorstwie, „Bezpieczeństwo Pracy” 2003, nr 2.

[13] Procesy i projekty logistyczne, red. Nowosielski S., Wydawnictwo Uniwersytetu Ekonomicznego we Wrocławiu, Wrocław 2008.

[14] Prognoza ekspertów dotyczqca nowych, pojawiajacych się ryzyk zwiqzanych z czynnikami fizycznymi w środowisku pracy (Export forecast on emerging physical risks related to occupational safety and health), Europejska Agencja Bezpieczeństwa i Zdrowia w Pracy, http://osha.eu.it [dostęp 20 marca 2007].

[15] Pysznik L., Chańska A., Stelmach K., Wypadki w budownictwie, Cz. 1, „Atest-Ochrona Pracy" 2011, nr 1.

[16] Pysznik L., Chańska A., Stelmach K., Wypadki w budownictwie, Cz. 2, „Atest-Ochrona Pracy" 2011, nr 2.

[17] Zapłata S., Zarzqdzanie jakościq w przedsiębiorstwie. Ocena i uwarunkowania skuteczności, Wydawnictwo Wolters Kluwer Polska Sp. z o.o., Warszawa 2009. 


\section{ZARZĄDZANIE PROCESOWE BEZPIECZEŃSTWEM PRACY W PRZEDSIĘBIORSTWIE NA PRZYKLADZIE BRANŻY BUDOWLANEJ}

W artykule zaprezentowano rolę i znaczenie bezpieczeństwa pracy i zarządzania zdrowiem pracowników dla funkcjonowania przedsiębiorstwa. Przedstawiono ideę organizacji procesowej oraz zarządzanie procesowe bezpieczeństwem i higieną pracy w przedsiębiorstwie. Ukazano także aktualny stan bezpieczeństwa pracy w budownictwie wraz $\mathrm{z}$ określeniem najczęściej występujących nieprawidłowości w tej branży.

DOI: 10.7862/rz.2012.zim.6 